九州大学学術情報リポジトリ

Kyushu University Institutional Repository

\title{
Human Prion Disease and Human Prion Protein Disease
}

\section{Kitamoto, Tetsuyuki}

Department of Neurological Science, Tohoku University School of Medicine

Tateishi, Jun

Department of Neuropathology, Neurologocal Institute, Kyushu University

http://hdl. handle. net/2324/6224

出版情報: Prions prions prions, pp.27-34, 1996. Springer-Verlag バージョン:

権利関係 : ๑ 1996 Springer-Verlag Berlin Heidelberg : This material is published with kind permission of Springer Science and Business Media. :Permission is obtained from the author 


\section{Human Prion Disease and Human Prion Protein Disease}

T. KITAMOto ${ }^{1}$ and J. TATEISHI ${ }^{2}$

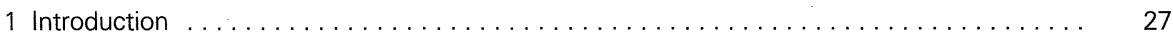

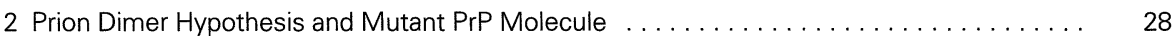

3 Only Mutant PrPsc Accumulates in the Central Nervous System (Prion Protein Disease) . . 28

4 Mutant PrPsc Influences the Wild PrPsc Conversion (Prion Disease) $\ldots \ldots \ldots \ldots \ldots \ldots$

5 A New Variant PrP Molecule in Gerstmann-Sträussler Syndrome . . . . . . . . . . . . . 32

References .................................. 33

\section{Introduction}

Creutzfeldt-Jakob disease (CJD), kuru, and Gerstmann-Sträussler syndrome (GSS) show clinical and pathological characteristics similar to those of scrapie, a transmissible neurodegenerative disease of sheep and goats. These diseases are caused by slow infectious agents designated as prions (PRUSINER 1982). The major component of prions is prion protein (PrP; McKINLEY et al. 1983), which is encoded in normal human genomes located on the short arm of chromosome 20 (SPARKES et al. 1986). In 1989 codon 102 or codon 117 point mutations of human PrP were reported to be linked to GSS (HSIAO et al. 1989; DoH-URA et al. 1989). The results in codon 102 transgenic mice also strengthen the idea that this mutation is one of the essential events that cause GSS (HsIAO et al. 1990). The several polymorphisms or mutations were also reported in familial CJD and familial dementia (Goldgarber et al. 1989; Goldfarb et al. 1991; Medori et al. 1992; Kitamoto et al. 1993a,b).

Recently, several studies showed that scrapie form of $\operatorname{PrP}(\operatorname{PrPSc})$ is an essential component of prions. These studies included the following results: copurification of PrPSc and scrapie infectivity (McKinLEY et al. 1983; GABIZON et al. 1988), PrPsc detection only in clones of cultured cell producing prion infectivity (TARABOulos et al. 1990), PrP amyloid plaque detections in prion diseases (BENDHEIM et al. 1984; KitAMOTO et al. 1986), genetic linkage between human PrP gene mutation and hereditary CJD or GSS (HSIAO et al. 1989, 1992; TRANCHANT et al.

\footnotetext{
${ }^{1}$ Department of Neurological Science, Tohoku, University School of Medicine, Sendai 980, Japan

${ }^{2}$ Department of Neuropathology, Neurological Institute, Kyushu University 60, Fukuoka 812, Japan
} 
1992; GoldFARB et al. 1992), and genetic linkage between mouse PrP gene and scrapie incubation time (WESTAWAY et al. 1987). One of the major confirmations is the result in PrP knockout (PrP\%) mice (BüELER et al. 1992). These PrP\% mice did not develop the scrapie and did not amplify the infectivity (prions titer; BüELER et al. 1993). Therefore, PrP is an essential component for the infectivity. However, the mechanism of prion multiplication is still unclear. One fascinating hypothesis (the prion dimer hypothesis) was proposed by PRUSINER (1991). This hypothesis can explain the infectious form of prion disease. We report here whether the dimer hypothesis can explain the human prion disease with germ-line mutation. We also report a new variant GSS with codon 102. Leu mutation and codon 219 Lys polymorphism.

\section{Prion Dimer Hypothesis and Mutant PrP Molecule}

The mechanism by which prions multiply is unknown. The multiplication of prion infectivity is an exponential process in which the posttranslational conversion of $\mathrm{PrPC}^{\mathrm{C}}$ (normal cellular form) to $\mathrm{PrP}^{\mathrm{Sc}}$ appears necessary. According to the prion dimer hypothesis, a PrPsc molecule combines with one $\mathrm{PrP}^{\mathrm{C}}$ molecule giving rise to one heterodimer. This heterodimer is subsequently transformed into one homodimer $\left(\mathrm{PrPs}^{\mathrm{Sc}} / \mathrm{PrP}^{\mathrm{Sc}}\right)$ that dissociates to combine with two $\mathrm{PrP}^{\mathrm{C}}$ molecules creating an exponential process.

In humans with $\operatorname{PrP}$ point mutation, mutant $\mathrm{PrP}^{\mathrm{C}}$ molecules might spontaneously convert into mutant $\operatorname{PrP}^{\mathrm{Sc}}$ (Fig. 1). While the initial stochastic event may be inefficient, once it happens, the process becomes autocatalytic. Whether all GSS and familial CJD patients contain infectious prions is unknown. If the former is found, mutant $\mathrm{PrPsc}^{\mathrm{sc}}$ molecules combine with the heterodimer (mutant $\mathrm{PrPsc} /$ wild $\mathrm{PrP}^{\mathrm{C}}$ ) and are subsequently transformed into mutant $\mathrm{PrPsc} /$ wild $\mathrm{PrP}^{\mathrm{Sc}}$. This wild $\mathrm{PrP}^{\mathrm{Sc}}$ produces the heterodimer (wild $\mathrm{PrP}^{\mathrm{sc}} /$ wild $\mathrm{PrP}^{\mathrm{C}}$ ) in a exponential process (Fig. 1). If the latter is found, presumably, mutant $\mathrm{PrP}^{\mathrm{sc}}$ molecules alone can produce the central nervous system dysfunction (Fig. 2). To test the dimer hypothesis we examined the following cases with unique point mutation or polymorphism.

\section{Only Mutant PrPsc Accumulates in the Central Nervous System (Prion Protein Disease)}

Most of the point mutations on the PrP gene were heterozygous and missense. Therefore it is difficult to analyze which molecule, wild or mutant, accumulated in the central nervous system because of the identical molecular weights. Previously we and another group identified the mutant PrP molecule (codon $102 \mathrm{Leu}$ 


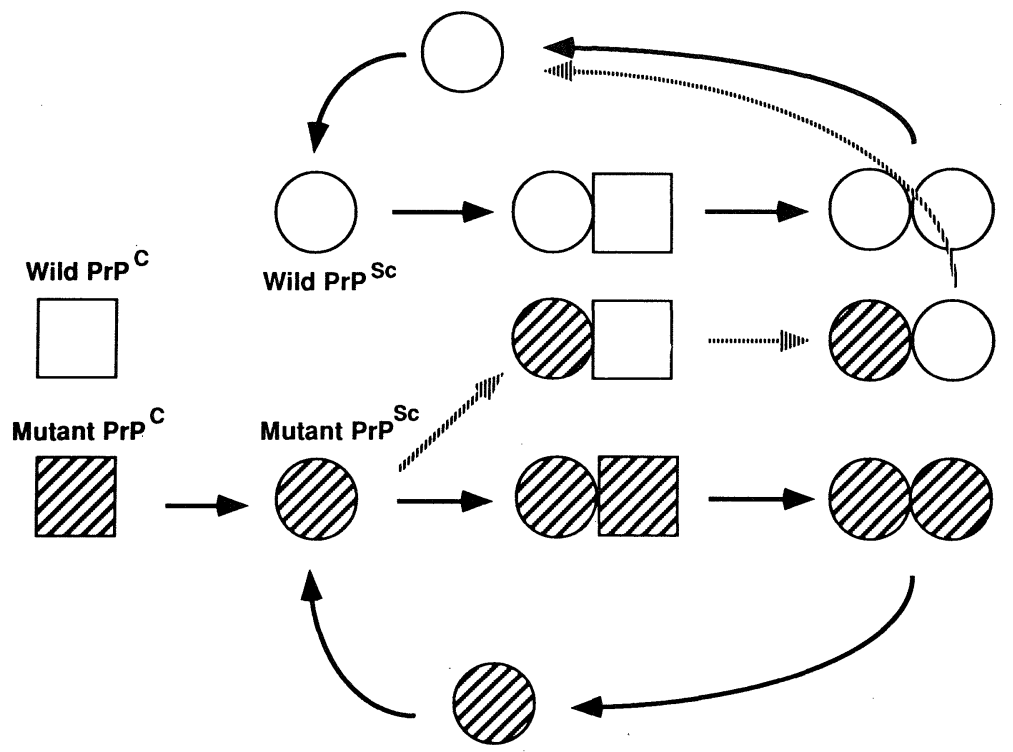

Fig. 1. Prion dimer hypothesis in inherited prion disease in humans. Mutant $\operatorname{PrP}^{\mathrm{C}}$ molecule (dashed line in squares) might initiate the conversion of $\operatorname{PrP}^{C}$ to $\operatorname{PrP}^{\mathrm{Sc}}$ (dashed line in circles). When infectious prions are produced, they stimulate the synthesis of mutant $\operatorname{PrP}^{\mathrm{Sc}}$ (dashed line) and wild $\operatorname{PrP}^{\mathrm{Sc}}$ (open circle)

\section{Wild PrP ${ }^{C}$}

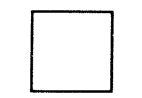

Mutant PrP ${ }^{C}$
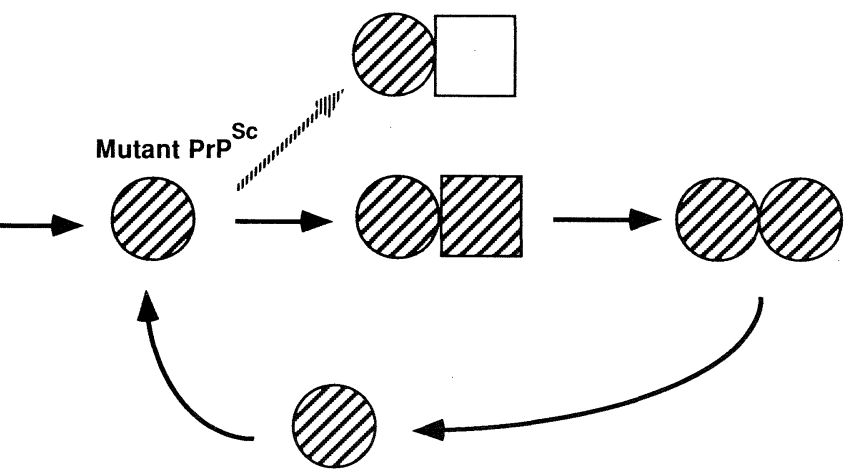

Fig. 2. Inborn error of PrP metabolism in humans. Mutant $\operatorname{Pr} P^{S c}$ molecule combine with only mutant $\operatorname{PrP}^{\mathrm{C}}$ molecule. Prion infectivity is not generated, but humans develops neurological dysfunction and PrP amyloid plaques

or codon $129 \mathrm{Val} / 198 \mathrm{Ser}$ ) from the kuru plaque core fractions of GSS patients (KITAMOTO et al. 1991; TAGLIAVINI et al. 1991). However, it remains to be established whether mutant PrP are major component of $\mathrm{PrP}^{\mathrm{Sc}}$. These peptide-sequencing data were based on a purification step which might cause the fragmentation of 
PrP or make it difficult to measure the concentration of mutant $\operatorname{PrP}$ in the kuru plaques.

Among these limitations of analyzing the mutant PrP molecules, we had a chance to examine a patient with Y145 stop mutation (KIтAмото et al. 1993a; Fig. 3). The T to $\mathrm{G}$ transition at codon 145 was resulted in tyrosine (TAT) to amber codon (TAG). To analyze this stop codon we used the following steps: (a) mRNA expression of mutant PrP in the brain, (b) western blotting, (c) protein expression in Escherichia coli and (d) immunohistochemistry using $\mathrm{N}$-terminal and $\mathrm{C}$-terminal antibodies.

First, we checked the mRNA expression with reverse-transcription polymerase chain reaction (RT-PCR) amplification. The RT-PCR product was digested with Mael endonuclease. The mutant PrP gene has a cutting site of Mael. Mael restriction fragment length polymorphism analysis revealed the expression of both wild and mutant PrP mRNA in the brain. Next, we performed western blotting using a proteinase-resistant prion rod fraction in the brain tissue to check for the low molecular weight mutant PrP. The western blot showed a diffuse smear immunoreactivity from the top of the gel to the dye front. The smear immunoreactivity, which may be due to the highly aggregated PrP of kuru plaques, makes it difficult to reveal small molecular weight mutant PrP. Thus we prepared a fusion protein expression plasmid in E.coli to check the specificity of the $\mathrm{N}$-terminal and $\mathrm{C}$-terminal PrP antibodies. $\mathrm{N}$-terminal antibody recognized both the wild and mutant PrP fusion protein, and $\mathrm{C}$-terminal antibody recognized only the wild PrP fusion protein. Finally, we examined the mutant PrP molecules in the tissue sections with these PrP antibodies. The N-terminal antibody immunostained positively with kuru plaques in the brain from this patient with Y145 stop, but the $\mathrm{C}$-terminal antibody did not immunolabel the kuru plaque. To confirm the immunoreactivity of the C-terminal antibody, we also immunostained the kuru plaques in the GSS patients with P102L mutation. This C-terminal antibody positively recognized kuru plaques in GSS102. Therefore, in this peculiar case, only mutant PrP molecules aggregated to form kuru plaques.

In this case, mutant $\operatorname{PrP}^{\mathrm{C}}$ molecules might spontaneously convert into $\operatorname{Pr} \mathrm{P}^{\mathrm{sc}}$. While the initial stochastic event may be inefficient, once it happens, the process becomes autocatalytic. Mutant PrP molecules alone produced the amyloid plaques in the central nervous system. Therefore this point mutation represents inborn errors of PrP metabolism (prion protein disease). Transmission study from this case to mouse also showed a negative result (0/10 mice).
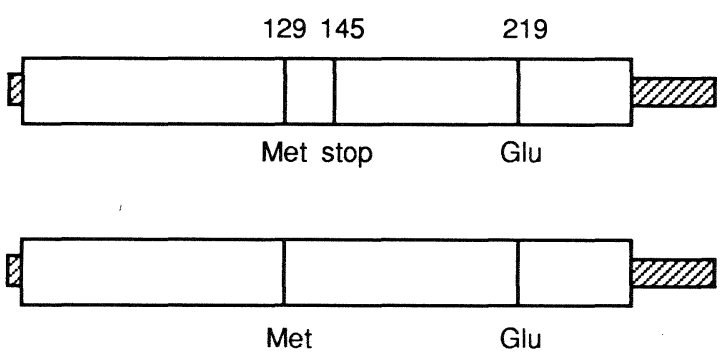

Fig. 3. PrP genotype of a patient with codon 145 mutation. Codon 129 and codon 219 representnormal polymorphism seen in Japanese 


\section{Mutant PrPsc Influences the Wild PrP ${ }^{\text {sc }}$ Conversion (Prion Disease)}

We have another case with codon 180 lle mutation and codon 129 Val polymorphism each on the different allele (Fig. 4). In our experience with codon 180 lle mutation, patients had only Met/Met type polymorphism at codon 129 and Glu/ Glu type polymorphism at codon 219. Neuropathological examinations showed typical spongiform changes and moderate neuronal loss in the cerebral cortices. Western blot analysis revealed $\mathrm{PrP}^{\mathrm{sc}}$, but the concentration of $\mathrm{PrPs}^{\mathrm{sc}}$ was much less than that of the wild-type CJD patients. The wild-type CJD patients have three major PrPsc bands, but CJD patients with codon 180 lle have two major bands corresponding to nonglycosylated and one glycosylated PrPsc (HוтоSH et al. 1993). PrP immunostainings showed diffuse gray matter stainings but not amlyoid plaques. In CJD cases with Val/Met or Val/Nal polymorphism at codon 129 we determined the amyloid plaque formation in the central nervous system (KITAMOTO et al. 1992; Mirazono et al. 1992). Therefore this patient is a suitable case to examine the both mutant (codon $180 \mathrm{lle}$ ) and wild (codon 129 Val) PrP molecules. Figure 5 shows the working hypothesis for detection of mutant and wild PrP molecules. Mutant $\operatorname{PrP}^{\mathrm{C}}(180 \mathrm{lle})$ might convert to mutant $\operatorname{Pr} \mathrm{P}^{\mathrm{Sc}}$. If the conversion occurs, the mutant $\mathrm{PrP} /$ mutant $\mathrm{PrPsc}$ heterodimer formation may result in the two mutant $\mathrm{PrP}^{\mathrm{Sc}}$ molecules. The interesting point is whether the wild $\mathrm{PrPC} /$ mutant $\mathrm{PrP}^{\mathrm{Sc}}$ heterodimer formation occurs. If the wild $\mathrm{PrP}^{\mathrm{C}}$ is converted to wild $\mathrm{PrPs}$, the process of wild $\mathrm{PrP}^{\mathrm{Sc}}$ formation becomes autocatalytic. These wild PrPsc (codon 129 Val) accumulations could be observed in the amyloid plaque formation in the central nervous system.

To examine this working hypothesis we at first analyzed the neuropathological findings of this case. Routine histopathological findings were severe spongiform changes and neuronal loss in the cerebral cortices, but no congophilic amyloid plaques. Western blot showed two lower PrPsc bands. The results of these histopathological and western blot analyses of this case are compatible with the findings seen in other CJD patients with codon 180 Ile. Finally, we examined PrP immunostainings using the hydrolytic autoclaving pretreatment. PrP immunostainings revealed weakly positive diffuse gray matter stainings and a few amyloid plaques. These amyloid plaques were not observed in other CJD
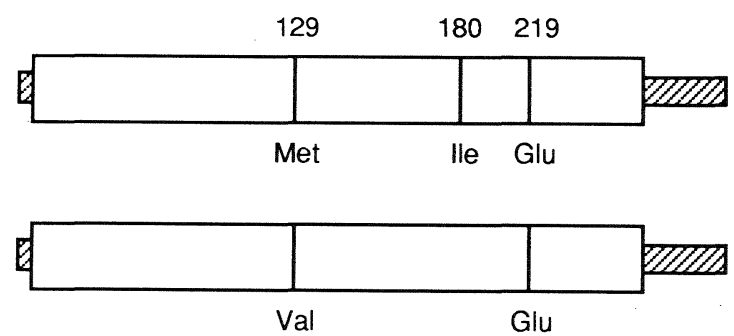

Fig. 4. PrP genotype of a patient with codon 180 mutation and codon 129 Val polymorphism 


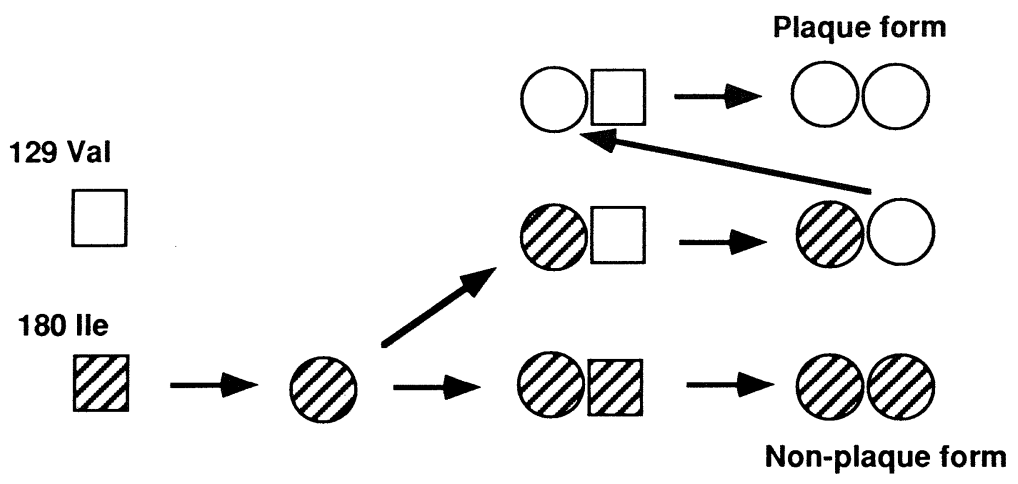

Fig. 5. Prion dimer hypothesis in a patient with codon 180 mutation and codon 129 Val polymorphism each on the different PrP allele

patients with codon 180 lle mutation and codon 129 Met/Met polymorphism. Therefore in this case wild $\mathrm{PrP}^{\mathrm{Sc}}$ molecules also accumulated in the central nervous system. Transmission experiment is now continuing.

\section{A New Variant PrP Molecule in Gerstmann-Sträussler Syndrome}

We determined the new polymorphism (codon 219 Glu or Lys) in a normal Japanese population (КITAMOTO and TATEISHI 1994). The allele frequency of codon 219 Lys is about 6\% in normal Japanese. During the search for this polymorphism codon 219 Lys was detected in four patients with Japanese Gerstmann-Sträussler syndrome (P102L). In three patients belonged to the different families, codon 102 Leu mutation was on the codon 219 Glu allele, but not on the codon 219 Lys allele. These three patients have a typical clinical course showing spinocerebellar degeneration. However, in one patient codon 102 Leu mutation was detected on the codon 219 Lys allele (Fig. 6). Family study revealed that four patients in this family have codon 102 Leu and codon 219 Lys on the same allele. Two patients showed only dementia in the absence of cerebellar signs, and two others showed weak cerebellar signs and dementia.

Recently we examined one autopsy case with a clinical course of dementia in the absence of cerebellar signs. Histopathological examinations showed no spongiform changes in the cerebral cortices. Mild gliosis and mild neuronal loss were observed in the deep layer of the cerebral cortices. There were no congophilic amyloid plaques in the cerebral and cerebellar cortices. The absence of amyloid plaques is quite different from GSS patients with only codon 102 Leu. Previously we examined more than 20 GSS patients with codon 102 Leu. These GSS patients have many congophilic plaques in the cerebral and cerebellar 
102129
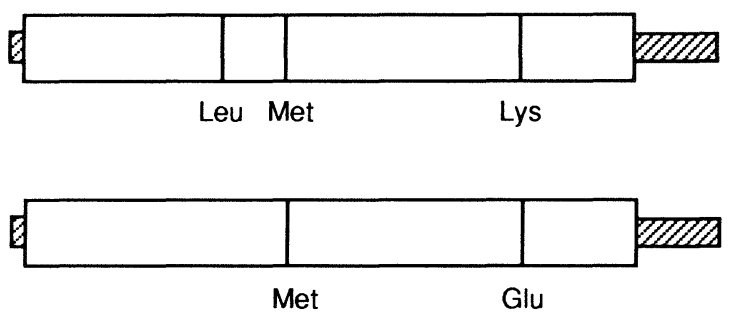

Fig. 6. PrP genotype of a new GSS family in Japan. The codon 102 Leu mutation is located on the codon 219 Lys allele

cortices, but this patient does not have congophilic plaques in routine histopathological examinations. PrP immunostainings revealed a few amyloid plaques in the molecular layer of the cerebellar cortices, and diffuse amyloid plaques, so-called moth-eaten PrP plaques, in the deep cortical layers of the cerebral cortices and basal ganglia. There were neither tau-positive neurofibrillary tangles nor senile plaques in the cerebral cortices.

These clinical and neuropathological findings support the hypothesis that codon 219 Lys polymorphism influences the phenotype of the codon 102 Leu mutation. Therefore it is better to classify as a new type GSS with codon 102 Leu/ codon 219 Lys.

Acknowledgments. We thank M. Yoneda and K. Hatanaka for technical assistance. This study was supported by a grant from the Science and Technology Agency, Grant-in-Aid for Scientific Research and a Grant-in-Aid for Scientific Research on Priority Area from the Ministry of Education, Science, and Culture, a grant from the Ministry of Health and Welfare, a grant from the Kato Memorial Trust for Manbyo Research, and a grant from Nambyo Medical Research.

\section{References}

Bendheim PE, Barry RA, DeArmond SJ, Stites DP, Prusiner SB (1984) Antibodies to a scrapie prion protein. Nature 310: 418-421

Büeler H, Fischer M, Lang Y, Bluethmann H, Lipp HP, DeArmond SJ, Prusiner SB, Aguet M, Weissmann C (1992) Normal development and behaviour of mice lacking the neuronal cell-surface PrP protein. Nature 356: $577-582$

Büeler H, Aguzzi A, Sailer A et al. (1993) Mice devoid of PrP are resistant to scrapie. Cell 73: 1339-1347

Doh-ura K, Tateishi J, Sasaki H, Kitamoto T, Sakaki Y (1989) Pro-Leu change at position 102 of prion protein is the most common but not the sole mutation related to Gerstmann-Sträussler syndrome. Biochem Biophys Res Commun 163: 974-979

Gabizon R, McKinley MP, Groth DF, Prusiner SB (1988) Immunoaffinity purification and neutralization of scrapie prion infectiviy. Proc Natl Acad Sci USA 85: 6617-6621

Goldfarb LG, Haltia M, Brown P, Nieto A, Kovanen J, McCombie WR, Trapp S, Gajdusek DC (1991) New mutation in scrapie amyloid precursor gene (at codon 178) in Finnish Creutzfeldt-Jakob kindred. Lancet 337: 425

Goldfarb LG, Petersen RB, Tabaton M, Brown P, LeBlanc AC, Montagna P, Cortelli P, Julien J, Vital C, Rendelbury WW, Haltia M, Wills PR, Hauw JJ, McKeever PE, Monari L, Schrank B, Swergold GD, Autilio-Gambetti L (1992) Fatal familial insommia and familial Creutzfeldt-Jakob disease: disease phenotype determined by a DNA polymorphism. Science 258: 806-809 
Goldgarber D, Goldfarb LG, Brown P et al. (1989) Mutations in familial Creutzfeldt-Jakob disease and Gerstmann-Sträussler syndrome. Exp Neurol 106: 204-206

Hitoshi S, Nagura H, Yamanouchi H, Sakuta M, Kitamoto T (1993) Double mutations at codon 180 and codon 232 of the PRNP gene in an apparently sporadic case of Creutzfeldt-Jakob disease. J Neurol Sci 120: 208-212

Hsiao K, Baker HF, Crow TJ, Poutler M, Owen F, Terwillinger JD, Westaway D, Ott J, Prusiner SB (1989) Linkage of a prion protein missense variant to Gerstmann-Sträussler syndrome. Nature 338: 342-345

Hsiao K, Dlouhy SR, Farlow MR, Cass C, Costa MD, Conneally PM, Hodes ME, Ghetti B, Prusiner SB (1992) Mutant prion proteins in Gerstmann-Sträussler-Scheinker disease with neurofibrillary tangles. Nature Genet 1: 68-71

Hsiao KK, Scott M, Foster D, Groth DF, DeArmond SJ, Prusiner SB (1990) Spontaneous neurodegeneration in transgenic mice with mutant prion protein of Gerstmann-Sträussler syndrome. Science 250: 1587-1590

Kitamoto T, Tateishi J (1994) Human prion diseases with variant prion protein. Philos Trans R Soc Lond [B] 343: 391-398

Kitamoto T, Tateishi J, Tashima T, Takeshita I, Barry RA, DeArmond SJ, Prusiner SB (1986) Amyloid plaques in Creutzfeldt-Jakob disease stain with prion protein antibodies. Ann Neurol 20: 204-208

Kitamoto T, Yamaguchi K, Doh-ura K, Tateishi J (1991) A prion protein missense variant is integrated in kuru plaque cores in patients with Gerstmann-Sträussler syndrome. Neurology 41: 306-310

Kitamoto T, Doh-ura K, Mutamoto T, Miyazono M, Tateishi J (1992) The primary structure of the prion protein influences the distribution of abnormal prion protein in the central nervous system. Am J Pathol 141: 271-277

Kitamoto T, Lizuka R, Tateishi J (1993a) An amber mutation of prion protein in Gerstmann-Sträussler syndrome with mutant PrP plaques. Biochem Biophys Res Commun 192: 525-531

Kitamoto T, Ohta M, Doh-ura K, Hitoshi S, Terao Y, Tateishi J (1993b) Novel missense variants of prion protein in Creutzfeldt-Jakob disease or Gerstmann-Sträussler syndrom. Biochem Biophys Res Commun 191: 709-714

McKinley MP, Boltn DC, Prusiner SB (1983) A protease-resistant protein is a structural component of the scrapie prion. Cell 35: $57-62$

Medori R, Tritschler HJ, LeBlanc A, Villare F, Manetto V, Chen HY, Xue R, Leai S, Montagna P, Gortelli P, Tinuper P, Avoni P, Mochi M, Baruzzi A, Hauw JJ, Ott J, Lugaressi E, Autilio-Gambetti L, Gambetti P (1992) Fatal familial insomnia, a prion disease with a mutation at codon 178 of the prion protein gene. N Engl J Med 326: 444-449

Miyazono M, Kitamoto T, Doh-ura K, Iwaki T, Tateishi J (1992) Creutzfeldt-Jakob disease with codon 129 polymorphism (valine): a comparative study of patients with codon 102 point mutation or without mutations. Acta Neuropathol (Berl) 84: 349-354

Prusiner SB (1982) Novel proteinaceous infectious particles cause scrapie. Science 216: 136-144

Prusiner SB (1991) Molecular biology of prion diseases. Science 252: 1515-1522

Sparkes RS, Simon M, Cohn VH, Fournier REK, Lem J, Klisak I, Heinzman C, Blatt C, Lucero M, Mohandas T, DeArmond SJ, Westaway D, Prusiner SB, Weiner LP (1986) Assignment of the human and mouse prion protein genes to homologous chromosomes. Proc Natl Acad Sci USA 83: 7358-7362

Tagliavini F, Prelli F, Ghiso J, Bugiani O, Serban D, Prusiner SB, Farlow MR, Ghetti B, Frangione B (1991) Amyloid protein of Gerstmann-Sträussler-Scheinker disease (Indiana kindred) is an $11 \mathrm{kd}$ fragment of prion protein with an N-terminal glycine at codon 58. EMBO J 10: 513-519

Taraboulos A, Serban D, Prusiner SB (1990) Scrapie prion proteins accumulate in the cytoplasm of persistently infected cultured cells. J Cell Biol 110: 2117-2132

Tranchant C, Doh-ura K, Warter JM, Steinmetz G, Chevalier Y, Hanauer A, Kitamoto T, Tateishi J (1992) Gerstmann-Sträussler-Scheinker disease in an Alsatian family: clinical and genetic studies. J Neurol Neurosurg Psychiatry 55: 185-187

Westaway D, Goodman PA, Mirenda CA, McKinley MP, Carlson GA, Prusiner SB (1987) Distinct prion proteins in short and long scrapie incubation period mice. Cell 51: 651-662 